\title{
Laparoscopic cholecystectomy in the treatment of biliary lithiasis: outpatient surgery or short stay unit?
}

\author{
A. Martínez Vieira, F. Docobo Durántez, J. Mena Robles, I. Durán Ferreras, J. Vázquez Monchul, \\ F. López Bernal and E. Romero Vargas
}

Service of General Surgery and Digestive Diseases. University Hospital Virgen del Rocío. Sevilla, Spain

\begin{abstract}
Objective: analysis of clinical and surgical factors in a series of patients subjected to laparoscopic cholecystectomy in an outpatient unit and their relationship with time of discharge and patient acceptance.

Patients and method: eighty one consecutive patients underwent to elective laparoscopic cholecystectomy during year 2002 within S.A.S. (Andalusian Health Service) from a surgical waiting list. Retrospective and comparative study between two groups: group A includes patients discharged between 24 and 48 hours after intervention; group B includes patients discharged in less than 24 hours. We analyse the clinical and surgical characteristics and post-operative outcome of both groups of patients.

Results: group A was composed of 53 patients and group B of 28 patients. Factors of clinical significance which determined discharge after 24 hours included: early post-surgical incidences or complications $(p=0.017)$, inability to tolerate oral diet $(p=$ 0.002), and doubts and feelings insecurity of patients regarding discharge by traditional means $62.3 \%(p=0.0003)$.

Conclusions: outpatient laparoscopic cholecystectomy is a safe and reliable procedure with a high acceptance rate and few complications. Perhaps traditional culture has to be changed to obtain better results.
\end{abstract}

Key words: Outpatient laparoscopic cholecystectomy. Perceived quality. Day surgery unit.

Martínez Vieira A, Docobo Durántez F, Mena Robles J, Durán Ferreras I, Vázquez Monchul J, López Bernal F, Romero Vargas E. Laparoscopic cholecystectomy in the treatment of biliary lithiasis: outpatient surgery or short stay unit? Rev Esp Enferm Dig 2004; 96: 452-459.

Recibido: 28-10-03

Aceptado: 12-01-04.

Correspondencia: Almudena Martínez Vieira. C/ Ceuta, 2, 3ํD. 01010 Cádiz. Telf.: 670448600 - 686439 002. e-mail: almulaciru@ hotmail.com

\section{INTRODUCTION}

A Day Surgery Unit (DSU) is characterised by performing surgical procedures which, carried out using whatever type of anesthesia, require a short post-operative period, and therefore patients can be discharged a few hours after the procedure (1). When it is necessary for patients to have a recovery period of more than 24 hours in hospital, with the subsequent increase in costs, we are faced with the concept known as Short Stay Surgery (SSS).

Laparoscopic cholecystectomy has been improved in such a way that, used in the treatment of non-complicated biliary lithiasis, it has become a part of the service offered by the SSS units and, nowadays, by the DSUs $(2,3)$. If this surgical activity is going to be carried out in a DSU as well as in Short Stay Units it is necessary an appropriate selection of patients, the establishment of protocols for each phase, and an adequate evaluation of the service offered. If these conditions are theoretically present in DSU as well as in SSS units, which factors will determine hospital stay and what makes a difference between both types of programs?

The aim of the present study was to analyse clinical and surgical factors in patients who underwent laparoscopic cholecystectomy in a DSU, which could be determinants in deciding to discharge patients on the same day of the procedure (DSU programme) or to discharge them after 24 hours of hospital stay (SSS Unit).

\section{PATIENTS AND METHODS}

We carried out a retrospective study on a series of patients who underwent laparoscopic cholecystectomy for uncomplicated biliary lithiasis during 2002 in the Day Surgery Outpatient Unit of the University "Hospital Virgen del Rocio", Seville. All these patients were potential candidates for outpatient treatment. 
Table I. Clinical data of patients in groups A and B

\begin{tabular}{ccccccc}
\hline $\begin{array}{c}\text { Women } \\
(\%)\end{array}$ & $\begin{array}{c}\text { Men } \\
(\%)\end{array}$ & Me age & $\begin{array}{c}\text { ASA I } \\
(\%)\end{array}$ & $\begin{array}{c}\text { ASA II } \\
(\%)\end{array}$ & $\begin{array}{c}\text { TBil } \\
\text { mean }\end{array}$ \\
\hline A & $48(91)$ & $5(9)$ & 54 & $21(38)$ & $32(62)$ & 0,69 \\
B & $18(64)$ & $10(36)$ & 50 & $12(44)$ & $16(56)$ & 0,75 \\
\hline
\end{tabular}

Me: median (years). TBil: total bilirubin ( $\mathrm{mg} / \mathrm{dl})$

Table II. Causes of hospitalization in group A patients

\begin{tabular}{lc}
\hline & $n(\%)$ \\
\hline Social reasons: (doubts, insecurity, others...) & $33(62,3)$ \\
Intolerance to diet & $11(20,8)$ \\
Uncontrolled pain & $3(5,7)$ \\
Vomiting & $2(3,8)$ \\
Abdominal drainage & $2(3,8)$ \\
Bleeding of surgical wound & $1(1,8)$ \\
Postintubation croup & $1(1,8)$ \\
\hline
\end{tabular}

n: number of patients

Criteria necessary for inclusion in this program of outpatient laparoscopic cholecystectomy included: a) suffering from biliary pain or chronic lithiasic cholecystitis; b) ultrasonography showing cholelithiasis with permeable, non-dilated bile duct; c) normal liver tests including total bilirubin of less than $1 \mathrm{mg} / \mathrm{dl}$; d) ASA I or II; and e) social conditions ensuring discharge accompanied by a responsible adult, telephone number, transport home and urgent evacuation.

All patients followed the normal procedures established by the DSU: signing of informed consent; performance and acceptance of a pre-anesthetic study; admittance to the unit one hour before the procedure in fasting conditions; blood reservation according to their blood group, and programmed pre-medication with midazolam and omeprazol. In the operating theatre they received a balanced general anesthetic. A prophylactic antibiotic, cefazoline, was administered, and a dressing was applied to the lower limbs of patients with distal vein problems or obesity. Laparoscopic cholecystectomy was carried out in all cases following the European technique. During the immediate post-operative period, monitoring was maintained in a recovery room; patients were then taken to hospital wards following anesthetic assessment, where normal nursing practices and a follow-up by the surgeon were carried out, the latter being also responsible for hospital discharge. Once this was decided, the patient and the person responsible for his/her care were properly informed on the treatment to be carried out (analgesia with ketorolac or paracetamol), and the instructions to follow during the post-operative period, as well as on contact phone numbers, a form to fill in to evaluate the process, and an outpatient clinic appointment for a check-up one month after the procedure.
The criteria for inclusion in our study were: a) conversion to laparotomy was not necessary; $b$ ) the procedure was performed by the same two surgeons; and c) the patients were discharged the same day or the day following the procedure.

Patients were divided into two groups (A and B), depending on the time when they were discharged. Group A patients were discharged between 24 and 48 hours after the procedure and required a one-day stay in hospital, and group B patients were discharged in less than 24 hours, without hospitalization. In both groups of patients, we analyzed: sex; age; distance from DSU to home (more or less than 20 kilometers); ASA; body mass index (BMI); total bilirubin; semester of the year in which the surgery was carried out; surgeon who performed the procedure (classified as I or II); time at which the patient tolerates oral diet; appearance of postoperative events (uncontrolled pain, vomiting) and complications (bleeding from surgical wounds, need for abdominal drainage, etc.); patient status within one month after the procedure, and pathological finding in the excised gallbladder.

Statistical analysis was aided by the SPSS program, version 11.0. Qualitative variables were compared using the Chi square test (Fisher's exact test). The Student's t test for unpaired samples was used to determine statistical difference between groups; $p$ values $<0.05$ were considered significant.

\section{RESULTS}

Eighty one out of 91 patients who underwent laparoscopic cholecystectomy during year 2002 have been included in this study. All of them satisfied the following criteria: a) they were discharged between 24 and 48 hours after the procedure and therefore they did not require hospitalization [group $\mathrm{A}=53$ patients, $(65 \%)$ ]; or $\mathrm{b}$ ) they were discharged in less than 24 hours, without need of hospitalization [group $\mathrm{B}=28$ patients $(35 \%)$ ].

In group A, $91 \%$ were women and $9 \%$ were men, with an average of 54 years; $41 \%$ of patients lived less than 20 kilometers away from the hospital; $38 \%$ were classified as ASA I, and $62 \%$ as ASA II. The mean BMI was 29 $\mathrm{kg} / \mathrm{m}^{2}$, and mean total bilirubin was $0.69 \mathrm{mg} / \mathrm{dl}$. Surgeon I carried out $60 \%$ of the cholecystectomies and surgeon II $40 \% ; 65 \%$ of these patients underwent surgery during the first six months of the year, and 35\% during the second half of 2002. Incidents and complications arose in 9 patients $(16.9 \%)$ and included: uncontrollable pain (3 cases), vomiting (2 cases), placing of an abdominal drain, which was withdrawn the following day (2 cases), wound dressing stained with blood (1 case), and slight respiratory problem after extubation (1 case). Eleven patients $(79.2 \%)$ tolerated an oral diet on the same day of the procedure. For the remaining 33 patients (62.3\%), hospital stay was finally determined by social reasons, mainly by insecurity or doubts about being discharged. Within a 
month of the procedure, $93 \%$ of patients were asymptomatic. Two patients presented a complication derived from surgery. One of them developed an umbilical hernia across the trocar incision and another an infection of the surgical wound. The histopathological study of the excised gallbladder, whose results were available approximately twenty days after the procedure, reported: unspecific chronic cholecystitis in $84 \%$ of cases, cholesterosis, in $12 \%$, and adenomiomatosis, in $4 \%$.

In group B, $64 \%$ of the patients were women, and 36\% men. The median age was 50 years; $51 \%$ of patients lived less than 20 kilometers away from the hospital; $44 \%$ of patients were classified as ASA I, and $56 \%$ as ASA II. The mean BMI of patients was $31 \mathrm{~kg} / \mathrm{m}^{2}$, and mean total bilirubin was $0.75 \mathrm{mg} / \mathrm{dl}$. Surgeon I carried out $65 \%$ of cholecystectomies, while surgeon II performed $35 \%$ of the procedures. Thirty per cent of these patients underwent surgery in the first six months of the year, and $70 \%$ during the second half of 2002. No immediate postoperative incidents arose, and no patient expressed doubt or insecurity on the proposal of being discharged on the same day of surgery. In no case was it necessary to place an abdominal drain; $100 \%$ of patients tolerated an oral diet on the same day of the procedure. Mean discharge time was 10 hours after the procedure. Within a month of the procedure, only one patient had diarrhea. In the definitive histopathological report, $73 \%$ of patients had unspecific chronic cholecystitis, $18 \%$ cholesterosis, and 9\% adenomiomatosis.

Regarding the sex variable, a larger percentage of females, as opposed to males, required hospitalization. However, this data reflects the greater number of women operated on, and the fact that group A contained more patients than group B (65 versus $35 \%$ ).

Analyses of these data showed statistically significant differences in the following variables: a) the need for hospitalization decreased significantly during the second semester of the year, as opposed to the first semester, as should be expected due to the development of a learning curve; b) incidents and complications are the major causes of hospitalization ( $\mathrm{p}=0.002)$; and $\mathrm{c}$ ) doubt and insecurity of patients regarding the proposal of being discharged on the same day of the procedure was a very significant reason for hospitalization $(p=0.0003)$.

\section{DISCUSSION}

The term DSU combines processes complementary to surgery performed using any type of anesthesia that require less intensive postoperative care and are of short duration; therefore patients do not need to stay in the hospital and can be discharged a few hours after the procedure (1).

A DSU permits an increase in surgical activity not limited by the number of beds, and reduces the cost of the process by $25-30 \%$. Compared to inpatient surgery, it re- duces the time a patient spends in hospital and therefore entails less interference in daily and working life (4).

The level of complexity of procedures that can be carried out in a DSU is increasing. But this advance means it will be necessary for patients to have a longer period of recovery, with a subsequent increase in costs. We are entering into what is known as a SSS, which may carry out surgical procedures with hospital stays between one and three days using hospital resources for the least time possible (5), although with greater financial cost when compared to a DSU.

Nowadays, for many authors, laparoscopic surgery for the treatment of uncomplicated biliary lithiasis is, along with the treatment of groin hernia, the laparoscopic procedure that can be carried out with greater safety and effectiveness on an outpatient basis $(6,7)$.

For a DSU program to be implemented, the following conditions are necessary: appropriate selection of patients according to a series of clinical, laboratory, and social criteria; establishment of protocols for each phase of the process; appropriate postoperative evaluation, and an assessment of quality for offered services. To evaluate the latter point it is necessary to focus on morbidity markers and quality as perceived by patients (8). One of the most commonly used markers is the rate of events and complications arising during the postoperative period (9). From what emerges from our study, and from data offered by other authors $(10,11)$, early postsurgical events (bleeding, vomiting, etc.) and clinical status of the patient after the procedure (pain, inability to tolerate food) are factors that most commonly determine the need for hospitalization and admission into a SSS, and consequently increasing the cost of the process. A prevention of such incidents is the best way to avoid hospital stays. To carry out this prevention, measures such as an exquisite and refined surgical technique to avoid, along with the appropriate analgesic procedures, the appearance of uncontrollable postoperative pain (12) are important, as is a rational use of antiemetics (13) with a gradual establishment of oral feeding, which should favor early tolerance to food. Other complications that lead to unexpected extension of the hospital stays (bleeding, drainage, etc.) could be avoided by careful hemostasis during surgery to avoid staining of cutaneous dressings; use of abdominal drains when necessary, strict antisepsis for the prevention of infections, use of antithrombotic agents on patients at risk, and an appropriate management of associated illnesses that frequently present these patients (diabetes mellitus, hypertension, asthma, etc.).

The experience of the surgeon who operates and discharges the patient is also important, as is that of all team involved in the unit, especially since the greater percentage of patients who remained in hospital had been operated on in the first months of 2002. Gradual staff learning accounted for a reduction in one-night admissions by $50 \%$, in favor of discharging the same day of the procedure in the second half of 2002 , without this 
involving an increase in postoperative complications or a decline in service quality. This fact demonstrates the importance of the so-called learning curve for attaining the fundamental objectives of a DSU: discharging without decreasing service quality as provided or perceived. Currently, our rate of discharges on the same day of the procedure is $73 \%$, a level similar to that reported in other series (14-16).

Lastly, it is necessary that discharge, and the knowledge of how to continue recovery at home, is accepted by the patient, and instructions to follow must be very clearly laid out for both patients and their families. Also relevant are the availability of a functioning well-developed follow-up system (17), including complication identification via the telephone and their solution by a surgeon. Even so, many patients choose to stay in hospital one day for no apparent reason, since they prefer the direct observation and care of professionals. This "social" reason for staying in hospital is a factor which significantly increases the percentage of unexpected prolonged stays in a DSU. It is basically determined by the traditional belief that a longer period of health care provides better results than an outpatient regimen. However, regardless of what surveys on satisfaction and perceived service quality indicate, discharging less than 24 hours after the procedure does not decrease quality or imply a greater number of complications in the following month. The only efficient way to prevent these hospital stays is comprehensive information and patient individualization.

We conclude that outpatient laparoscopic cholecystectomy is a safe and reliable procedure with a high level of acceptance. In general, events emerging in the early postoperative period can be considered a statistically significant determinant for patient admission. Variables such as doubt or insecurity of patients at discharge can be important factors when it comes to deciding on admission. Cultural tradition, i.e., that more time spent in hospital improves both quality of care and results, must change. Comprehensive information and patient individualization are efficient and valid measures to prevent admissions for social reasons (doubt and insecurity of patients at discharge). We believe that, as long as the clinical status is suitable in the postoperative period, discharge on the same day of the procedure should be the option of choice.

\section{REFERENCES}

1. Porrero JL. Cirugía Mayor Ambulatoria. Madrid: Doyma, 1999. p. 425.

2. Campanelli G, Cavagnoli R, Cioffi U, De Simone M, Fabianni M, Pietri P. Can laparoscopic cholecystectomy be a day surgery procedure. Hepatogastroenterology 1998; 45: 1422-9.

3. Keulemans Y, Eshuis J, de Haes H, de Wit L, Gonma DI. Laparoscopic cholecystectomy: day-care versus clinical observation. Ann Surg 1998; 228: 734-40.

4. Marín J, Prieto A, Otero JA. Cirugía Mayor Ambulatoria: Experiencia de la Unidad de Cirugía de Día del Hospital de El Tomillar. Sevi1la. Gestión Hospitalaria 1993; 3: 44-8

5. Fatas JA. Cirugía de Corta Estancia. En: Maestre JM .Guía para la planificación y desarrollo de un programa de Cirugía Mayor Ambulatoria. Séneca Farma, 1997. p.175-85.

6. Galindo A, Docobo F, Almeida S, Martín J, Razzak C. Cirugía biliar en las unidades de corta estancia. Rev And Pat Digest 1998; 21: 36-9.

7. Docobo F, Galindo A, Mena J, Martín J, Santos, Fernández A, et al. La colecistectomía laparoscópica en unidades de Cirugía Mayor Ambulatoria: resultados de dos años de tratamiento. Rev And Pat Digest 1999; 22: 167-70.

8. Planells M, Sánchez A, Sapabuiia A, Bueno J, Serralta A, García R, et al. Gestión de la calidad total en colecistectomía laparoscópica. Calidad asistencial y calidad percibida en colecistectomía laparocópica ambulatoria Rev Esp Enferm Dig 2002; 94 (6): 319-31.

9. Raich M. Complicaciones postalta en cirugía ambulatoria. En: Carrasco MS. Anestesia para la cirugía ambulatoria, tomo II. Barcelona: Edika-Med 1999. p. 293-52.

10. Robinson TN, Biffl WL, Moore EE, Heimbach JK,Calkins CM, Buurch JM. Predicting failure of outpatient laparoscopic cholecystectomy. Am J Surg 2002; 184 (6): 515-8.

11. Serralta A, García R, Martínez P, Hoyas L, Planells M. Cuatro años de experiencia en colecistectomía laparoscópica ambulatoria. Rev Esp Enferm Dig 2001; 93 (4): 207-13.

12. Smith I. Anesthesia for laparoscopy with emphasis on outpatient laparoscopy. Anesthesiol Clin North America 2001; 19 (1): 21-41.

13. García S, González A, Vidal M. Use of ondansetron for prevention of postoperative nausea and vomiting in major ambulatory surgery. Rev Esp Anestesiol Reanim 1996; 43 (8): 300-1.

14. Pardo J, Ramia R, Martín JM, López A, Padilla D, Cubo T, et al. Colecistectomía laparoscópica ambulatoria. Cir Esp 1998; 64: 37-9.

15. Narain PK, DeMaria EJ. Initial results of a prospective trial of outpatient laparoscópica cholecystectomy. Surg Endosc 1997; 11: 1091-4.

16. MjAland O, Raeder J, Aasboe V, Trondsen E, Buanes T. Outpatient laparoscopic cholecstectomy. Br J Surg 1997; 84: 958-61.

17. Lau H, Brooks DC. Contemporary outcomes of ambulatory laparoscopic cholecystectomy in a major teaching hospital. World J Surg 2002; 26 (9): 1117-21. 


\title{
Colecistectomía laparoscópica en el tratamiento de la litiasis biliar: ¿cirugía mayor ambulatoria o corta estancia?
}

\author{
A. Martínez Vieira, F. Docobo Durántez, J. Mena Robles, I. Durán Ferreras, J. Vázquez Monchul, \\ F. López Bernal y E. Romero Vargas
}

Servicio de Cirugía General y Aparato Digestivo. Hospital Universitario Virgen del Rocío. Sevilla

\section{RESUMEN}

Objetivo: analizar los factores clínicos y quirúrgicos que en una serie de pacientes sometidos a colecistectomía laparoscópica ambulatoria influyeron en la decisión del momento del alta y cuál fue la aceptación de los pacientes al alta.

Pacientes y método: en este estudio fueron incluidos 81 pacientes consecutivos procedentes de la lista de espera quirúrgica en quienes se realizó una colecistectomía laparoscópica electiva a lo largo del año 2002. Es un estudio retrospectivo y comparativo que incluye dos grupos de pacientes: los del grupo A fueron dados de alta entre 24 a 48 horas tras la intervención; los del grupo B lo fueron en menos de 24 horas. Analizamos las características clínicas, quirúrgicas y evolución postoperatoria de ambos grupos de pacientes

Resultados: el grupo A estaba compuesto por 53 pacientes. El Grupo B por 28 pacientes. Los factores con significación estadística que determinaron que el alta se prolongara más de 24 horas fueron: las incidencias o complicaciones postquirúrgicas precoces $(p=0,017)$, la no tolerancia oral de alimentos $(p=0,002)$ y las dudas o inseguridad de los pacientes ante el alta determinada por la tradición cultural $(62,3 \% ; p=0,0003)$.

Conclusiones: la colecistectomía laparoscópica ambulatoria es un procedimiento seguro y realizable, con un elevado porcentaje de aceptación y escasas complicaciones. Quizás se deba cambiar la tradición cultural para obtener mejores resultados.

Palabras clave: Colecistectomía laparoscópica ambulatoria. Calidad percibida. Cirugía mayor ambulatoria.

\section{INTRODUCCIÓN}

La cirugía mayor ambulatoria (CMA) se caracteriza por atender procesos quirúrgicos, que realizados con cualquier modalidad anestésica, requieren un postoperatorio corto. Por esta razón, los pacientes pueden ser dados de alta a las pocas horas de la intervención (1). Cuando estos pacientes necesitan un periodo de recuperación de más de 24 horas de ingreso, con el consiguiente incremento del coste económico, estamos ante lo que se conoce con el concepto de cirugía de corta estancia (CCE).

La colecistectomía laparoscópica se ha perfeccionado de tal manera que, empleada para el tratamiento de la litiasis biliar no complicada, ha entrado a formar parte de las ofertas de los programas de CCE y, actualmente, de los de CMA $(2,3)$.

Para que el desarrollo de esta actividad quirúrgica se lleve a cabo tanto en CMA como en CCE, son necesarias varias condiciones: una adecuada selección de los pacientes, el establecimiento de protocolos para cada una de las fases y una valoración posterior de la asistencia ofrecida. Si estas condiciones están teóricamente presentes tanto en CMA como en CEE, ¿cuáles son los factores que determinan el ingreso hospitalario y que marcan la diferencia entre los dos tipos de programas?

El objetivo del presente estudio es analizar los factores clínicos y operatorios en pacientes sometidos a colecistectomía laparoscópica en una UCMA, que puedan ser determinantes para decidir el alta el mismo día de la intervención (CMA propiamente dicha) o tras 24 horas de ingreso hospitalario (cirugía de corta estancia).

\section{PACIENTES Y MÉTODOS}

Se ha realizado un estudio retrospectivo de una serie de pacientes sometidos a colecistectomía laparoscópica por litiasis biliar no complicada durante el año 2002, en la Unidad de Cirugía Mayor Ambulatoria del "Hospital Universitario Virgen del Rocío de Sevilla". Todos estos pacientes eran potencialmente candidatos de ambulatorización.

Las condiciones necesarias para ser incluidos en el programa de colecistectomía laparoscópica ambulatoria fueron: a) padecimiento de cólicos biliares de repetición o colecistitis crónica litiásica; b) demostración ecográfica de la colelitiasis con vía biliar permeable no dilatada; c) normalidad de las enzimas hepáticas y bilirrubina total inferior a $1 \mathrm{mg} / \mathrm{dl}$; d) ASA I-II; y e) condiciones sociales que garanticen que en el momento del alta se esté acompañado de un adulto responsable, número de teléfono, traslado al domicilio y evacuación urgente.

Todos los pacientes siguieron los trámites habituales establecidos en la unidad de CMA: firma del consentimiento informado; realización y aceptación de estudio preanestésico; ingreso en la unidad una hora antes de la interven- 
ción, en ayunas; reserva de sangre según grupo sanguíneo y premedicación programada vía oral con midazolan y omeprazol. En quirófano recibieron anestesia general balanceada. Se administró antibioterapia profiláctica con cefazolina, y se aplicó un vendaje de miembros inferiores en aquellos pacientes que presentaban problemas venosos distales u obesidad. En todos los casos se realizó una colecistectomía laparoscópica según la técnica europea. Durante el postoperatorio inmediato se mantuvo la monitorización en la sala de despertar, pasando, tras valoración por el anestesista, a las salas de hospitalización, donde se realizaron los controles habituales por la enfermería y el seguimiento por el cirujano. Este fue también el encargado del alta hospitalaria. Una vez decidida esta, se informó convenientemente al paciente y a la persona encargada de su cuidado del tratamiento a realizar (analgesia con ketorolaco o paracetamol) y las instrucciones a seguir durante el postoperatorio, así como las referencias en caso de necesidad (teléfono de urgencias), hoja a cumplimentar para valoración del proceso y citación en consultas externas para revisión al mes de la intervención.

Los criterios para ser incluidos en nuestro estudio fueron: a) no haber sido necesaria la conversión a laparotomía; b) haber sido intervenidos por los mismos dos cirujanos; y c) haber sido dados de alta el mismo día o al día siguiente de la intervención.

Los pacientes fueron divididos en dos grupos (A y B) dependiendo del momento en el que se les dio el alta: el grupo A estaba formado por pacientes que fueron dados de alta entre las 24 y las 48 horas de la intervención y que requirieron un día de ingreso hospitalario. Los pacientes del grupo B fueron dados de alta en menos de 24 horas y no requirieron ingreso hospitalario.

Los datos analizados en ambos grupos de pacientes fueron: sexo, edad, distancia del centro de CMA al domicilio del paciente (mayor o menor de 20 kilómetros); ASA, índice de masa corporal (IMC), cifra de bilirrubina total; semestre del año en el que se realizó la cirugía; cirujano que realizó la intervención (se tipifican como I ó II); momento de inicio de tolerancia a dieta oral; incidencias postoperatorias surgidas (dolor no controlable, vómitos) y complicaciones (sangrado por las heridas quirúrgicas, necesidad de drenaje abdominal, etc.); situación del paciente al mes de la intervención y estudio anatomopatológico de la vesícula biliar extirpada.

El análisis estadístico de los datos se realizó con ayuda del programa SPSS v.11.0. Las variables cualitativas fueron comparadas mediante la pruebas del Chi cuadrado (prueba exacta de Fischer). La prueba t de Student para datos no apareados la utilizamos para la comparación de medias. Consideramos significativas las $\mathrm{p}<0,05$.

\section{RESULTADOS}

De los 91 pacientes intervenidos mediante colecistectomía laparoscópica durante el año 2002, se han incluido en esta revisión a 81 pacientes, que son los que cumplían los criterios de: a) alta entre 24 y 48 horas, requiriendo ingreso hospitalario (grupo $\mathrm{A}=53,65 \%$ de los pacientes); o b) alta en menos de 24 horas, sin requerir ingreso (gupo $\mathrm{B}=28,35 \%$ de los pacientes).

En el grupo A el $91 \%$ eran mujeres y el $9 \%$ varones; la mediana de edad fue de 54 años. El $41 \%$ de los pacientes tenían su domicilio a menos de 20 kilómetros del centro hospitalario. El $38 \%$ presentaban un ASA I, y el $62 \%$ un ASA II. El índice de masa corporal (IMC) medio fue de $29 \mathrm{~kg} / \mathrm{m}^{2}$ y la media de bilirrubina total de $0,69 \mathrm{mg} / \mathrm{dl}$. El cirujano I realizó el $60 \%$ de las colecistectomías y el cirujano II el 40\%. El $65 \%$ de estos pacientes se sometieron a la cirugía durante los seis primeros meses del año y el $35 \%$ restante durante la segunda mitad del 2002. Surgieron incidencias y complicaciones postoperatorias en 9 pacientes $(16,9 \%)$. Estas consistieron en dolor no controlable (3 casos), vómitos (2 casos), colocación de drenaje abdominal, que fue retirado al día siguiente (2 casos), manchado de sangre del apósito (1 caso), problema respiratorio leve tras extubación (1 caso). El 79,2\% de los pacientes (11 casos) toleró la dieta oral el mismo día de la intervención. El resto de pacientes, 33 casos $(62,3 \%)$, refirieron un motivo social que determinó finalmente el ingreso hospitalario, manifestado fundamentalmente como inseguridad y dudas ante el alta. Al mes de la intervención el $93 \%$ de los pacientes se encontraban asintomáticos. Dos pacientes presentaron alguna complicación derivada de la cirugía: una hernia umbilical a través de la incisión del trócar y una infección de herida quirúrgica. El informe anatomopatológico definitivo, que se obtuvo aproximadamente a los veinte días de la intervención, mostró: colecistitis crónica inespecífica en el 84\% de los casos, colesterolosis en el $12 \%$ y adenomiomatosis en el $4 \%$.

En el grupo B, el 64\% fueron mujeres y el 36\% varones. La mediana de edad fue de 50 años. El $51 \%$ de pacientes tenía el domicilio a menos de 20 kilómetros del hospital. El $44 \%$ de los pacientes presentaban un ASA I y el $56 \%$ un ASA II. El IMC medio de los pacientes era de $31 \mathrm{~kg} / \mathrm{m}^{2}$ y la bilirrubina total de $0,75 \mathrm{mg} / \mathrm{dl}$. El cirujano I realizó el $65 \%$ de las colecistectomías y el cirujano II, el $35 \%$ restante. El $30 \%$ de estos pacientes se sometieron a la cirugía durante los seis primeros meses del año y el 70\% durante la segunda mitad del 2002. No surgió ninguna incidencia postoperatoria inmediata y ningún paciente mostró duda o inseguridad ante la propuesta de alta hospitalaria el mismo día de la cirugía. En ningún caso fue necesaria la colocación de drenaje abdominal. El $100 \%$ de los pacientes toleró dieta oral el día de la intervención. El alta hospitalaria se concedió a las 10 horas de la intervención como término medio. Al mes de la intervención, tan sólo un paciente refería diarrea. En el $73 \%$ de los pacientes, el estudio anatomopatológico mostró la existencia de una colecistitis crónica inespecífica, en el 18\% colesterolosis y en el 9\% restante adenomiomatosis. 
Respecto a la variable sexo de los pacientes, se observó un mayor porcentaje del mujeres respecto al de hombres en el grupo que requirió ingreso hospitalario; sin embargo, este dato se comprende por el mayor número total de mujeres intervenidas y porque el grupo A contiene a más pacientes que el grupo B (65 frente al 35\%).

Del análisis de los datos se obtienen diferencias estadísticamente significativas en las siguientes variables: a) la necesidad de ingreso disminuyó significativamente durante el segundo semestre del año 2002, en relación con el primero, como cabría esperar como consecuencia del desarrollo de la curva de aprendizaje; b) las incidencias y complicaciones en el postoperatorio eran causas de ingreso $(\mathrm{p}=0,017)$; $)$ la no tolerancia a la dieta oral era un motivo obvio de ingreso $(\mathrm{p}=0,002)$; y d) la duda e inseguridad de los pacientes ante la propuesta de alta el mismo día de la cirugía fue un motivo muy significativo de ingreso $(\mathrm{p}=0,0003)$.

\section{DISCUSIÓN}

El término cirugía mayor ambulatoria (CMA) atiende a pacientes con procesos subsidiarios de cirugía, realizados con cualquier tipo de anestesia, que requieren cuidados postoperatorios poco intensivos y de corta duración, por lo que los pacientes no necesitan ingreso hospitalario y pueden ser dados de alta pocas horas tras el procedimiento (1).

La CMA permite un aumento de la actividad quirúrgica sin estar limitada por la disponibilidad de camas, reduce el coste por proceso en un $25-30 \%$, frente a la cirugía con ingreso, disminuye la estancia hospitalaria del paciente y supone una menor interferencia en su vida diaria y laboral (4).

El nivel de complejidad de los procesos que se realizan en CMA está aumentando. Pero, este avance supone la necesidad de que los pacientes requieran un periodo de recuperación más prolongado, con el consiguiente incremento del coste. Entramos en lo que se conoce como Cirugía de Corta Estancia (CCE), que resuelve procedimientos quirúrgicos con estancias hospitalarias de entre uno y tres días, utilizando los recursos hospitalarios durante el menor tiempo posible (5), aunque con mayor coste económico que la CMA.

En estos momentos, para muchos autores, la cirugía laparoscópica en el tratamiento de la litiasis biliar no complicada, es, junto con el tratamiento de la hernia inguinal, el procedimiento laparoscópico que puede ser realizado de manera ambulatoria con mayor seguridad y eficacia $(6,7)$.

Para que el programa de CMA se lleve a cabo son necesarios los siguientes requisitos: adecuada selección de pacientes según una serie de criterios clínicos, analíticos y sociales; establecimiento de protocolos para cada una de las fases del proceso; evaluación postoperatoria correcta y valoración de la calidad de la asistencia ofrecida.
Tabla I. Datos clínicos de pacientes de los grupos A y B

\begin{tabular}{|c|c|c|c|c|c|c|}
\hline \multicolumn{2}{|c|}{$\begin{array}{c}\text { Mujeres } \\
\text { (\%) }\end{array}$} & \multicolumn{2}{|c|}{$\begin{array}{l}\text { Hombres Me edad } \\
\text { (\%) }\end{array}$} & \multirow{2}{*}{$\begin{array}{c}\text { ASA I } \\
(\%)\end{array}$} & \multirow{2}{*}{$\begin{array}{c}\text { ASA /I } \\
(\%) \\
32(62)\end{array}$} & \multirow{2}{*}{$\begin{array}{c}\text { Bb T } \\
\text { media }\end{array}$} \\
\hline $\bar{A}$ & $48(91)$ & $5(9)$ & 54 & & & \\
\hline B & $18(64)$ & $10(36)$ & 50 & $12(44)$ & $16(56)$ & 0,75 \\
\hline
\end{tabular}

Tabla II. Causas del ingreso en el grupo A

\begin{tabular}{lc}
\hline & $n(\%)$ \\
\hline Motivos sociales: (dudas, inseguridad, otros, etc.) & $33(62,3)$ \\
No tolerancia a dieta & $11(20,8)$ \\
Dolor no controlado & $3(5,7)$ \\
Vómitos & $2(3,8)$ \\
Drenaje abdominal & $2(3,8)$ \\
Sangrado incisión quirúrgica & $1(1,8)$ \\
Crup postintubación & $1(1,8)$ \\
\hline n: número de pacientes &
\end{tabular}

Para valorar esta última es necesario centrarse en indicadores de morbilidad y calidad percibida por el paciente (8). Uno de los indicadores más utilizados es la tasa de incidencias y complicaciones surgidas durante el postoperatorio (9). Según lo que se desprende de nuestro análisis, y coincidiendo con lo descrito en otras series $(10,11)$, las incidencias postquirúrgicas precoces (sangrado, vómitos...) y el estado clínico del paciente después de la intervención (dolor, no tolerancia a dieta) son factores que, con mayor frecuencia, determinan la necesidad de hospitalización e ingreso en régimen de CEE, incrementando el coste del proceso. La prevención de dichas incidencias es la mejor forma de evitar el ingreso hospitalario; para llevar a cabo esta prevención son importantes medidas como: utilizar una técnica quirúrgica exquisita y depurada que evite, junto a los procedimientos analgésicas adecuados, la aparición de dolor postoperatorio no controlable (12) y el empleo racional de antieméticos (13) con instauración progresiva de la dieta oral, que favorezca la tolerancia alimenticia temprana. Otras complicaciones que condicionarían ingresos no esperados (sangrados, drenajes...) se prevendrían mediante una hemostasia cuidadosa en quirófano que evite el manchado de los apósitos cutáneos; el empleo de drenajes abdominales cuando sea necesario; la antisepsia estricta para la prevención de infecciones; el uso de procedimientos antitrombóticos en pacientes de riesgo y el manejo adecuado de las enfermedades asociadas que, con frecuencia, presentan los pacientes (diabetes mellitus, hipertensión arterial, asma, etc.).

También es importante la experiencia del cirujano que interviene y da el alta y la de todo el personal integrante de la unidad, tanto más cuanto, en el mayor porcentaje de los pacientes que quedan ingresados han sido interveni- 
dos durante los primeros meses de 2002. El aprendizaje progresivo por parte de todo el personal, ha permitido una reducción del $50 \%$ de los ingresos de una noche a favor del alta el mismo día de la intervención, en la segunda mitad de 2002, sin que esto signifique un aumento de las complicaciones postoperatorias o una merma en la calidad de la asistencia ofrecida. Este hecho demuestra la importancia de la denominada curva de aprendizaje y la necesidad de esta para la consecución de los objetivos fundamentales de la CMA: ambulatorización sin disminución de la calidad ofrecida y percibida. En la actualidad, nuestra cifra de altas el mismo día de la intervención se sitúa en el 73\% de las pacientes, cifra similar a la descrita en otras series (14-16).

Por último, es necesaria la aceptación del alta por el paciente y el conocimiento de cómo continuar la recuperación en su domicilio, para lo cual se le debe de informar con claridad a él y a su familia de las instrucciones a seguir, y la disposición de un sistema bien desarrollado y que funcione correctamente (17), de seguimiento, detección de complicaciones vía telefónica y resolución de las mismas por el cirujano correspondiente. Aún así, muchos pacientes, sin referir realmente ningún motivo clínico optan por permanecer ingresados un día, ya que prefieren la vigilancia y los cuidados profesionales directos. Esta causa "social" de ingreso, es un factor que incrementa significativamente el porcentaje de ingresos no esperados en
CMA. Está condicionada fundamentalmente por la creencia tradicional de que un mayor periodo de asistencia sanitaria proporcionaría mejores resultados que los obtenidos con el régimen ambulatorio; sin embargo, tal y como se desprende de las encuestas de satisfacción de la calidad asistencial percibida por los usuarios, el alta antes de las 24 horas desde la intervención no disminuye dicha calidad, y tampoco implica un mayor número de complicaciones al mes de la cirugía. La única forma eficaz de evitar estos ingresos es la información exhaustiva y la individualización de los pacientes.

Concluimos que la colecistectomía laparoscópica ambulatoria es un procedimiento seguro y realizable, con un elevado porcentaje de aceptación. En general, las incidencias surgidas en el postoperatorio temprano pueden ser consideradas, de manera estadísticamente significativa, causas determinantes de ingreso de los pacientes. Variables como, la duda e inseguridad del paciente al alta, pueden ser factores importantes a la hora de determinar el ingreso. Se debe cambiar la tradición cultural de que mayor tiempo de ingreso mejora la calidad asistencial y los resultados. La información exhaustiva y la individualización de los pacientes son medidas eficaces y válidas para evitar los ingresos por causa social (duda e inseguridad del paciente al alta). Creemos que, siempre que el estado clínico en el postoperatorio sea el adecuado, debe optarse por el alta el mismo día de la intervención. 